\title{
Challenges Facing Horticulture in a Changing World Presidential Address ${ }^{1}$
}

\author{
Daniel J. Cantliffe ${ }^{2}$ \\ ASHS President, 1994-95
}

I'll never forget the Presidential Address my friend, Dick Lower, gave at the 88th Annual Meeting of the American Society for Horticultural Science held at Penn State Univ. in 1991. He started his talk off by saying "It is an honor and a privilege to present the presidential address..." Well, if I may reiterate this message, it is truly an honor and an extreme pleasure, and most importantly, a privilege to be here addressing you, the Membership of ASHS.

However, let me reflect-did you ever sit down and try to write 12 "Reflections" columns for the ASHS Newsletter? It's a seemingly impossible task, especially to get them in on time. So is writing the Presidential Address. Fortunately, this Address has been written and published in my 12 "Reflections" columns, each column spelling out and discussing challenges that are facing horticulture, horticulturists such as you and me, and ASHS.

I found an easy way to get an ASHS Presidential Address-buy a copy of Jules Janick's book on ASHS Presidential Addresses! When you read through that compilation of great literature, one thing becomes apparent-all the Addresses start looking similar. In my particular case, I've been writing and giving this talk for the past year in Mexico, New Orleans, Spain, China, and anywhere else that I could find someone to listen.

While attending the ASHS Southern Region meeting in New Orleans this past January, President Glen "Cat" Taylor also was observed to be reading Janick's book. In his address, Cat made mention of all the changes and challenges facing horticulture and horticulturists. He read a list of seemingly unending problems, challenges, and needs for change that faced horticulturists since 1903. This list went right up to Benton Storey's message at last year's ASHS meeting in Oregon. What Cat Taylor's message brought out was, So what's new? He went back to our beginning as a Society and found that we as a profession and a Society are constantly facing new problems and, thus, are constantly changing and evolving.

\footnotetext{
${ }^{1}$ Presented at the 92nd Annual Meeting of the American Society for Horticultural Science, Montreal, Quebec, Canada, 2 Aug. 1995.

Viewpoints are published in HortScience to provide Members of the American Society for Horticultural Science an opportunity to share their experiences and comments on matters of concern to horticulturists. These are not statements of official Society policy, nor do they necessarily reflect the views of a majority of the Society's members.

${ }^{2}$ Horticultural Sciences Dept., 1255 Fifield Hall, P.O. Box 110690, Univ. of Florida, Gainesville, FL 32611-0690.
}

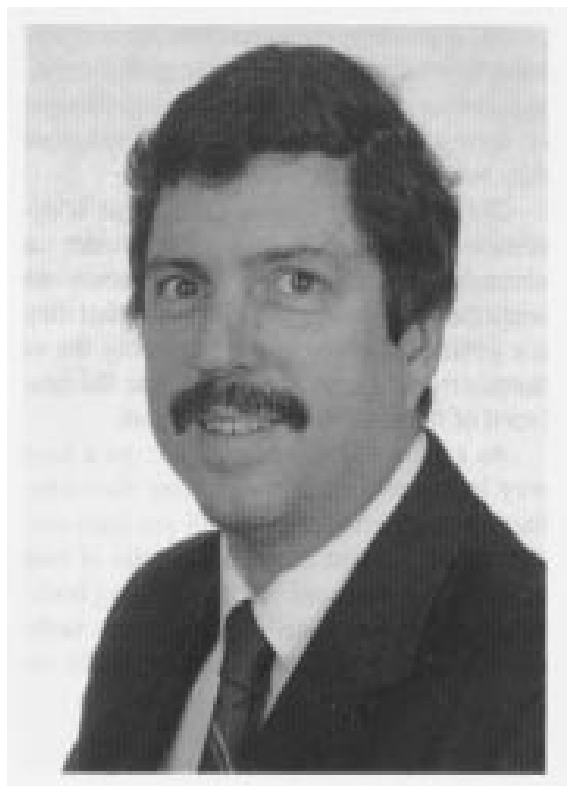

I noted several things from reading Janick's book: that the ASHS President in 1919, John Warren Crow, was a Canadian. Crow was a young ASHS President (42) and was a young (35) Dept. of Horticulture Head at the Univ. of Guelph. At the age of 55 he retired and moved to Simcoe, Ont. - the place that I started my career. Another thing I noted was that our 1988 President, Jim Moore, used the title of my talk for his Presidential Address. Jim also reviewed previous Presidential Addresses and reflected on contrasts of "then and now."

As your President this past year, I am convinced that at no other time in history have changes been more rapid and challenges been greater than at present.

As horticulturists, we learn and share our knowledge and expertise globally. Our diversity and strength come from our interactions with horticulturists around the world. Over the past quarter century, many things have changed to vastly improve horticultural production and marketing. New varieties, the intensive use of plastics as protectants and mulches, new chemicals for use as pesticides and growth stimulants, the ability to use methyl bromide effectively as a field fumigant, improved irrigation practices with drip and microjet water placement, new and improved methodologies for postharvest handling of produce, computeraided marketing, and jet-age transportation are only a few of the dramatic changes taking place in the horticultural industries worldwide.

How did so many changes take place over such a short period of time? Essentially, all of the new breakthroughs can be traced back to scientific research that has been published in various journals, especially those journals and publications sponsored by scientific horticultural societies. One prime example of a major breakthrough that comes to mind is referenced by the work of Shmueli and Goldberg reported in a 1971 HortScience issue wherein four concurrent articles described trickle irrigation practices for muskmelon, pepper, sweet corn, tomato, cucumber, and onion on work done in 1967 and 1968 in Israel. When you think of it, the system appeared quite simplistic, but the results changed irrigation practices the world over. Presently, drip irrigation has brought us new ideas of water and fertilizer conservation, while continually increasing plant productivity.

New varieties for many years were the net result of academic and public institutions. However, beginning in the late 1970 s to present, we have observed major changes in germplasm invention and release. Seed companies began to hire breeders with advanced degrees ( $\mathrm{PhDs}$ ), hybrid varieties took over the marketplace for many crops, and varieties began being patented in various parts of the world. Presently, we are experiencing a trend in the vegetable seed business wherein more and more international seed companies are being bought out and combined, potentially restricting vegetable germplasm.

As science progresses, we begin to observe even more rapid changes, including introduction of new and/or foreign genes into horticultural plants through plant molecular biology and plant transformation. Such events as resistance to tristeza virus in citrus, resistance to glyphosate in lettuce, altered ripening patterns in tomato and strawberry, and virus protection in squash and watermelon are but a few products of the new biotechnology research.

How do all of these new revelations relate to horticultural scientists and horticultural scientific societies? As science helps build a better, more efficient, agricultural production system, it sometimes engenders mistrust and complacency by those who benefit most from these changes. Environmentalists attack agriculture as a major polluter with pesticide and fertilizer use. Methyl bromide has been banned from agricultural use in 2001 because it is thought to be an ozone-depletor. Urbanization of prime farmland and subsequent land value changes threaten our best (and usually warmest) horticultural production land. With increased population comes the ever increasing demands for water quantity and quality by nonagricultural users.

What are the challenges and why might they be more difficult to deal with now than in the past? Maybe one area being challenged is complacency - the feeling that we have been there, seen it, done it, lived through it. How do you direct research programs where the scien- 
tist must obtain most of his or her funding from sources outside of the organization? How do you teach students that aren't there because students don't know of agriculture as a profession and a career? How do you enroll students into horticultural programs when they can't spell horticulture, let alone define the word horticulture? What is basic science and why is molecular biology more important than horticulture? Who will extend the agricultural research technology when states and the federal government cease funding the extension service?

The trends are real. How many colleges and universities have agricultural colleges and curricula? How many agricultural colleges have stand-alone horticulture departments? How many faculty are horticultural scientists and Members of ASHS? How many fruit, vegetable, and ornamental breeding programs are publicly funded? Is the U.S. Dept. of Agriculture (USDA) expanding? Are commercial agricultural firms, pesticide, seed, fertilizer, etc., companies expanding? Are these companies increasing their staff? Enough of these probing questions. I think that you should have the picture by now.

The good things that horticultural scien- tists have added to humanity are well spelled out in Janick's book. The benefits of the Hatch Act and other agricultural-related federal legislation also have been well documented in various USDA books of recent time, including the annual USDA Yearbook of Agriculture. But, daring yet another question, who cares besides us? Too many people, too much food, too much crime, a poor economy, too few people dependent on agriculture for a livelihood, too much pollution, cancer, global warming, and on and on. If we care, the challenges are up to us to take on, to solve, to offset before they become impossible problems.

Only by joining together can we as horticulturists continue to make this impact on scientific progress. We as horticulturists can continue to educate the public as to what they are getting from our work. And only we as horticulturists can train and educate the new breed of horticulturists for the future.

As a scientific society, we can go a long way to improve our future. More than onethird of the Members of ASHS are from outside of the United States. This tells of true common international interests among horticulturists. Presently, ASHS is discussing methods to interact with other horticulturally re- lated societies and associations to focus on issues that might affect political and public opinion on horticulture. We also are exploring closer contacts with regional groups, including a new Asian-Pacific Group wherein 15\% of our Members reside. Our membership search is first and easiest for traditional horticultural scientists and focuses both inside and outside of the North American borders. Our long-term job will be to add to our diversity of members within our borders through alignment with nonscientifically oriented horticultural persons. We need horticulturists all over the world to join together to help the progress of horticultural invention of the past 25 years continue through the next 25 years.

We, as a Society, are rapidly moving into the future. Some may say too rapidly, but in reality, probably not rapidly enough. Excellence, diversity, and membership must continue to be our goals as a Society of and for the future.

\section{References}

Janick, J. (ed.). 1994. Presidential addresses. Amer. Soc. Hort. Sci., Alexandria, Va.

Lower, R.L. 1991. Horticulture at risk; Presidential address. HortScience 26:1447-1450. 